\title{
Integrated Commercial Activities and Intangible Consumption in Cities Development
}

\author{
Roberta Tresca*
}

\begin{abstract}
The transformations taking place in consumers' behaviour, brought on by the growing importance attributed to intangible elements in purchasing decisions, induce the different places of purchase, gravitating to the area (urban or rural), to enhance the intangible components of its marketing system. This article examines the way the different commercial centres are responding to the need for intangible consumer products. In particular, we will examine the case of the city of Pescara.
\end{abstract}

Keywords: Places of Purchase; Retailing; Intangible Consumption; Area (Urban or Rural); City of Pescara

\section{Large Out-of-Town Shopping Complexes and Intangible Consumption}

The transformations taking place in consumers' orientation and behaviour, brought on by the growing importance that the latter attribute to intangible and symbolic elements in their purchasing decisions, have triggered a process of modernisation of the Italian commercial system. There has been intense growth and innovation in the field of so-called modern retailing, with the emergence of a vast range of structures and complexes, in which shops coexist with other type of activity (commercial services, culture, knowledge, entertainment, hospitality, leisure time). Commercial areas develop different forms of specialisation and supply, generating new forms of aggregation and different types of attraction for increasingly demanding consumers. Recurrent situations have 'standardised' the main types of integrated commercial activities now to be found: for example, shopping malls, multiplex cinemas ${ }^{1}$, factory outlets, etc.

The high level of dynamism that currently characterises these centres of consumption is reflected in the birth of new retail formats, which propose constantly evolving consumption and leisure time models, most of which are located in the suburbs or right outside the town, often generating significant territorial polarity.

Often, innovative retail formulae originate from the transformation of traditional shopping centres. When the phenomenon of the implosion of retail and entertainment

\footnotetext{
*Associate Professor of Management, University of Chieti-Pescara 'G. D'Annunzio', (r.tresca @unich.it)
}

Edited by: ISTEI - University of Milan-Bicocca

ISSN: 1593-0319

Tresca Roberta, Integrated Commercial Activities and Intangible Consumption in Cities Development, Symphonya. Emerging Issues in Management (symphonya.unimib.it), n. 1, 2011, pp. 68-77 
is very strong in the latter, it becomes necessary to redefine the way the centres are used, as they are becoming increasingly similar to amusement parks. For example, this is the case of the so-called shopping and leisure centres, a formula that is halfway between a shopping centre and a theme park, where it is the services and the entertainment facilities (restaurants, multiplex cinema, fitness centre, entertainment activities) rather than the traditional shops that attract the consumer. In the new integrated retail structures, changes are taking place in what was for a long time the anchor of the shopping centre; it was traditionally the supermarket, but is now tending to be identified more with activities/services of an intangible nature (cinemas, fitness centres, entertainment, food court, etc.) (Wolf 1999).

Ultimately, the configuration developed by these innovative retail formats has a dual function, which is both instrumental (shopping for something) and hedonistic (shopping around), attenuating the differences between the two. It embraces both routine purchasing (usually at a hypermarket) and more symbolic purchasing (in specialist stores), right down to leisure activities, linked to the consumption of services or just strolling. Shopping complexes become places where the individual can not only purchase goods but also pass his free time and satisfy his desire for amusement. The playful component that many large shopping complexes introduce when they propose various types of attractions, adjacent to and intermingled with the retail spaces, blends perfectly with the post-modern consumer's desire and search for pleasure, and offers him a familiar place to consume assets, spend time and gratify his emotions. Large retail centres thus come to resemble museums or theme parks, and can be considered leisure complexes like the latter (Ahtola, 1985).

If the basic lever that made it possible to increase the flow of visitors to conventional shopping complexes (shopping malls in particular) has traditionally been their size, which offered all visitors a wide variety of goods to choose between, now the basic competitive variables in which to invest lie primarily in the enhancement of the space in which the purchasing and consumption experience takes place (Schmitt 1999; Schmitt, Vrotsos 2003), by proposing a heterogeneous mix of elements (services, activities) with a specifically intangible content, which together satisfy new demands from the public, linked to leisure time, cultural consumption, physical well-being, etc.

To be precise, we could say that today the attraction of these centres is not determined by the tangible aspect of the products available there so much as by a system of intangible determinants on which the consumption experience is founded. We can break it down into two sub-systems: one that comprises the intangible contents of additional elements that contribute to the overall supply system (this refers to the presence of well-being centres, food courts, cinemas, etc.); and another that comprises intangible product components, which typically embody the brand (for example, the presence of products from well-known brands), design (the presence of products with a particular design), and before and after-sale services (Brondoni 2010b).

Regarding this sub-system of intangible components, it appears evident that today, when the consumer decides to purchase a product, rather than assessing the physical prerogatives associated with it, he attributes a decisive role to the various intangible attributes that combine to define it. In other words, what prompts a consumer to visit one point of sale rather than another is often determined by the possibility of finding products from a particular brand or with a particular design, or by the promise of particular before-sales services and/or after sale support. 
We can therefore say that the large purpose-built commercial complexes are now becoming the most wide-spread expression of a new paradigm that is taking shape in the commercial world. It is not linked to a specific formula but to an environment, a space in which it is the intangible components of the overall supply system that act as a motor to create value.

In the current age of intangibility, large out-of-town retail centres are acquiring a particular, innovative character: from containers of goods, which are considered primarily for their tangible prerogatives, they are becoming places that favour intangible product components, from purchasing centres to theatres of experience, from simple shopping places to places to spend time, places where people can enjoy their leisure time, taking advantage of new benefits in the field of animation, entertainment, information and knowledge; from places that express forms of traditional commercial exchange to places for economic and social meeting and aggregation, where people can relate to other people, socialise and immerse themselves in a welcoming, familiar environment; from simple spaces that act as a link between production and consumption, to platforms of relationships, where the customer is involved in purchasing experiences that are stimulating and to a certain extent gratifying, which satisfy a wide range of intangible needs for growth, comparison, knowledge, information, socialising, relaxation, entertainment, etc.

\section{Shopping Places in Town Centres and the Intangibility of Consumption}

The large out-of-town complexes have responded successfully to the demands of intangible consumption, primarily investing in the creation of contexts where people can enjoy different experiences through the proposal of an integrated range of products, and envisaging activities/services that are inherently intangible, alongside leisure-time facilities, culture, knowledge, physical well-being, etc.

The development of these out-of-town retail hubs could have a physical impact on the commercial fabric existing in the towns themselves, generating a gradual reduction in the commercial importance of spontaneous marketplaces compared to that of purpose-built out-of-town centres. In other words, although the small shops in the town centre often represent a large, strong commercial network that is deeply rooted in the territory, their attraction for local residents and consumers could be imperilled by the threatening presence of large out-of-town shopping centres, which they are unable to face up to because of their small size and the difficulty of finding resources for development.

However, if we look more closely, the small shops in town centres are potentially able to stave off the impact exerted by large retail structures by gradually upgrading the contents of their overall range, which can be achieved by enhancing the intangible attributes rather than only the physical aspects. In other words, if instead of adopting a 'neo-mercantile' logic, which takes the form of investing exclusively in the material/tangible values of supply, shops located in urban areas are able to redefine themselves as places whose products stand out for their intangible characteristics, we will note a revitalisation of urban commerce, an increase in value which, from the individual sales outlets, will have positive repercussions for the entire retail system and, as a result, for the entire urban context.

The activation of advanced policies by commercial structures in urban areas, to develop/enhance the intangibles of consumption and production, can only prove to 
be a successful approach, in view of the current state of the economic and market environment in which companies operate. In other words, the state of structural oversupply that currently exists in numerous markets, induced on one hand by an overabundance of the products on offer and, on the other, by a substantial saturation of the consumption requirements of demand, has produced a situation in which purchasers today are motivated by the desire to possess a specific product, rather than by the need to acquire any product provided it can meet the individual's primarily basic needs. The elementary use associated with a product (whether an item of clothing, a food product, a car, etc.) is now taken for granted by the consumer, while the presence of intangible attributes of the product, such as the brand, design, the colour, warranty, various services associated to the sale of the asset, etc. become decisive. Basically, when purchasing a product, objective and tangible performance is considered on a par with prerequisites, characteristics that the asset must have, but which do not qualify it any more. What the consumer looks for - and buys - is related increasingly to the intangible element that defines the supply and is expressed in the product intangible assets ${ }^{2}$.

Anyway, the shared recognition of the primary role that product intangibles play in consumers' purchasing decision-making processes should induce the management of urban retail establishments to make necessary adaptations to their management policies, which should in fact strive to exploit the intangible assets on which a company's success is founded today. In urban sales outlets it will therefore be necessary to pursue a method of producing value that draws less on tangible elements and increasingly on the significance that the product acquires during the consumption experience, exploiting all the 'soft' components of the supply that contribute in various ways to satisfaction of the demand for intangible aspects of demand. As we mentioned, these may be product intangible assets, but also elements, themselves intangible, that qualify the place where the purchase is made and which satisfy the aesthetic demands of the post-modern consumer in particular. The latter are not identified exclusively with the striving for beauty as an added value of the product (for example, the important role played by design), but also with the demand for an aesthetic value of all acts of consumption. They invest in the 'ambiance' of the places where people purchase and/or consume (i.e. in particular by creating a particularly captivating atmosphere, and the attractive interior design of a place where people consume food or culture, or purchase goods) (Donovan, Rossiter, Marcoolyn, Nesdale, 1994).

Ultimately, if we start by acknowledging that the aspects linked to the physicality of the product tend to be gradually obscured by its intangible components, we can see that the key to success for the creation of value by commercial companies in the third millennium consists in investing in the intangible assets of products as a whole, shifting attention from exclusively material gratification to some form of cognitive, cultural, emotional and rational gratification.

Enhancing the intangible components of their supply system will help small town centre shops to successfully balance the well-known competitive advantages of large out-of-town shopping centres, such as price, parking and services. And at the same time it will simultaneously dilute the dualistic/confrontational logic between large purpose-built out-of-town complexes and points of sale in town centres, because they are very different shopping spaces, both striving to enhance the intangible determinants of supply. 
The revitalisation of trade in the town, which relies on recognition of the important role of intangible supply factors, will certainly have positive repercussions for the town and the population: the town will go back to being part of the lives of the residents-consumers, the preferred location for shared experiences, relations, social life, and a connector of unique experiences. In other words, the revitalisation of the urban areas will be expressed in the enlargement of the catchment basin, accompanied by an increase in the traffic of goods and people in the heart of the town.

If we look closely, this change from what we could call 'traditional' town trade to 'innovative' trade, which relies on intangible assets, could also be significantly 'assisted' by the implementation of systems of town governance that favour interventionist policies designed to create synergies between commercial companies, between companies and institutions, and between commercial companies and other types of enterprise belonging to the same urban context and operating in the context of an intangible consumer economy (Warnaby, Bennison, Davies, Hughes 2004).

In other words, in the age of the intangible, it is indispensable for commercial companies to overcome sterile and short-sighted individual operating logics and to take on board the concept of a network of relationships, an integrated long-term network. In other words they should prepare to work with a mentality based on the importance attributed to relations with parties (both public and private) operating in the various sectors of culture, knowledge, and entertainment. This will make it possible to develop or boost their respective products in a logic of mutual involvement, and to succeed in composing a systemic and integrated supply, which is able to foster the demand for intangible consumer products in the territory. Joint operation, based on interdependence between parties in the system and on mechanisms of coordination and integration, makes it possible to construct successful 'supply containers' that are able to attract demand flows for intangible consumer products by adopting processes to create and transfer knowledge (Brondoni 2010a).

To this end, the propulsive role performed by town governance in fuelling and sustaining relational and integrational logics between commerce and everything that revolves around intangible consumer economics will be decisive.

Very basically, the governance of our towns in the third millennium, designed to achieve goals of growth, development and the creation of value in the territory, must address the creation of new contexts in which commerce can achieve suitable integration with activities and services, but also with the places earmarked for culture, entertainment and social relations, adopting mechanisms and rules based on coordination and relationships.

In this regard, a new management tool known as Town Centre Management, is already taking hold in numerous foreign countries and is currently being experimented in a number of national Italian towns. It appears to be able to foster the coordinated management of town centres, aiming to exploit/promote the process of integration between commerce and services-culture-animation-entertainment, thanks to the coordinated administration of promotional, managerial and communications policies in urban areas. It also aims to be an innovative model for the organisation of mixed activities in public spaces, and specifically of commercial, craft, service, cultural and entertainment enterprises, which are coordinated and integrated by the town's overall development policy (Tomalin 1997; Tomalin, Pal 1994). 


\section{Out-of-Town Commercial Structures, Urban Commercial Areas and the Intangibility of Consumption. The Case of Pescara}

The city of Pescara, which stands at the mouth of the river by the same name, has the largest population of the cities in the Abruzzo region. It can boast a strong commercial tradition. There are numerous small, medium and large retail centres in the urban and out-of-town areas, the larger ones being located mainly in the city suburbs and in neighbouring municipalities.

The goal of this article is to highlight how the peripheral commercial structures and those in the urban area react to the current trend for intangibility in consumption.

\subsection{Large Out-of-Town Retail Centres in the Pescara Area and the Intangibility of Consumption}

Today, in the Pescara area, at a distance of no more than $25 \mathrm{~km}$ from the city centre, there are numerous large retail centres which attract huge numbers of visitors, particularly at the weekends.

Our analysis aims to investigate the propensity of these large-size retail structures to implement policies designed to develop intangible consumption, particularly by studying the distribution of the services and the entertainment areas at their interior.

By limiting the investigation to 8 integrated retail structures ${ }^{3}$, the study undertaken has highlighted the existence within each of the facilities investigated of a significant mixture of activities and services which, although very diverse, successfully satisfy the need for intangible consumption.

In greater detail, our analysis revealed that all retail structures invest constantly in the realisation of renewal programmes based on the enhancement/strengthening of the intangible assets in their systems. In this regard, as well as offering a comprehensive range, new services connected to leisure time and various conveniences, they attribute great importance to the architectural aspects, inside and outside the centre, focusing on certain fundamental elements such as: usability, practicality, atmosphere and attractiveness, in order to offer visitors a more comfortable, welcoming environment in which to enjoy their free time.

Where the impact on the territory is concerned, large purpose-built retail centres have encouraged an important process of requalification in the hinterland of the city of Pescara. All around the large areas occupied by the retail centres, a number of residential complexes have sprung up, revitalising parts of the territory that were once deserted. There has also been a significant increase in traffic due to the increased movement of goods and people generated by the retail centres themselves.

\subsection{Commercial Urban Areas and Intangible Consumption}

The city centre of Pescara is relatively modern, having developed after the Second World War ${ }^{4}$.

In spite of the economic crisis and the continuous proliferation of large retail centres, commerce in the urban area of Pescara has not been penalised significantly, nor has there been any drastic reduction in traffic flow in the city centre. This might on one hand seem to be due to the type of products sold by many shops in the centre, some of which stand out and differentiate themselves from those offered in the nearby out-of-town purpose-built centres ${ }^{5}$. On the other hand, it could derive from 
the propensity of individual points of sale to upgrade their products, investing in enhancing their intangible benefits. One significant element in this regard is the attention focused on enhancing the consumption experience inside the individual store. A growing number of points of sale are dedicating particular attention to the atmosphere inside the store, where the ambiance itself promotes the product, and there are also numerous sales outlets that offer options that are not strictly linked to product sales; for example by combining the sale of goods with attractive relaxation and meeting areas.

The desire to further boost the value of urban commerce and its capacity to attract, by pursuing a policy of town development linked to investments in intangibility by the activation of mechanisms of collaboration and mutual integration (involving public and private players), has prompted many local administrations to approve the project to implement Town Centre Management in our towns.

The project envisages significant investments in favour of the organisation of events linked to entertainment and animation, and the creation of infrastructure that is closely linked to intangible assets such as information, communication and the use of new technologies.

One aspect that characterises the retail sector in the city of Pescara, which we believe can be a factor behind the activation of coordinated urban development policies to exploit the demand for intangible consumption in the area, is the latter's form widespread ownership. In other words the non-oligopolistic proprietary configuration typical of the retail sector trade in Pescara, simplifies the activation of mechanisms of collaboration and mutual integration. This avenue makes it possible to favour the development of a supply system that emerges from the integration between retail and the economics of intangibles. In this regard, it might be useful to activate or strengthen integration mechanisms between commercial activities and, in particular, the many locations in the municipal territory that could be defines as centres of culture and knowledge, but also of leisure, enjoyment and entertainment. These 'social areas' already play a part in fostering the development of the urban territory, generating a strong attraction of demand flows, by organising important cultural events, but they could further increase their contribution to the creation of value in the city by activating mechanisms and rules based on integration, relations and coordination with commercial activities.

\section{Bibliography}

Ahtola Olli T., Hedonic And Utilitarian Aspects Of Consumer Behavior: An Attitudinal Perspective, Advances in Consumer Research, vol. 12, (ed) E.C. Hirschman e M.B. Holbrook, Provo UT: Association for Consumer Research, 1985, pp. 7-10.

Alzubaidi Hassan, Vignali Claudio, Davies Barry F., Schmidt Ruth A., Town Centre Versus Out-OfTown Shopping: A Consumer Perspective, International Journal of Retail \& Distribution Management, vol. 25, n. 2, 1997, pp. 78-89. http://dx.doi.org/10.1108/09590559710160373

Bennison David, Warnabey Gary, Pal John, Local Shopping In The UK: Towards a Synthesis of Business and Olace, Emerald 38, 2010. http://dx.doi.org /10.1108/09590551011085948

Bromley Rosemary D.F., Thomas Colin T., Small Town Shopping Decline: Dependence and Inconvenience for the Disavantaged, The International Review of Retail, Distribution and Consumer Research, vol. 5, n. 4, 1995, pp. 433-456. 
http://dx.doi.org /10.1080/09593969500000025

Brondoni Silvio M., Brand Policy and Brand Equity, Symphonya. Emerging Issues in Management (symphonya.unimib.it), n. 1, 2000-2001, pp. 5-25.

http://dx.doi.org/10.4468/2001.1.02brondoni

Brondoni Silvio M, Intangibles, Global Networks and Corporate Social Responsability, Symphonya. Emerging Issues in Management (symphonya.unimib.it), n. 2, 2010, pp. 6-24. http://dx.doi.org/10.4468/2010.2.02brondoni

Brondoni Silvio M., Ouverture de 'Intangible Assets and Global Markets', Symphonya. Emerging Issues in Management (symphonya.unimib.it), n. 2, 2010b, pp. 1-5.

http://dx.doi.org/10.4468/2010.2.01ouverture

Cloar James A., Stabler Elizabeth, Devito Antony P., Centralized Retail Management: New Strategies for Downtown, Urban Land Inst, November, 1990.

D'Arcy Eamonn, Keogh Goffrey, Territorial Competition And Property Market Process: An Exploratory Analysis. Urban Studies, n. 8, 1998.

http://dx.doi.org/ 10.1080/0042098984330

Dhar Ravi, Wertenbroch Klaus, Consumer Choise between Hedonic and Utilitarian Goods, Journal of Marketing Research, vol. 37, n. 1, 2000, pp. 60-71.

http://dx.doi.org/10.1509/jmkr.37.1.60.18718

Donovan Robert J., Rossiter John R., Marcoolyn Gilian, Nesdale Andrew, Store Atmosphere and Purchaising Behavior, Journal of Retailing, n. 70, 1994, pp. 283-294.

http://dx.doi.org/10.1016/0022-4359(94)90037-X

Evans Richard, Regenerating Town Centres, Manchester University Press, Manchester, 1997.

Falk Pasi, Campbell Colin (ed), The Shopping Experience, London: Routledge, 1997.

Greenland Steven J., McGoldrick Peter J., Atmospherics, Attitudes and Behavior: Modeling the Impact of Designed Space, The International Review of Retail, Distribution and Consumer Research, vol. 4, n. 1, 1994, pp. 1-16.

http://dx.doi.org/10.1080/09593969400000001

Guy Clifford M., The Retail Development Process: Location, Property and Planning, London: Routledge, 1994.

Holbrook Morris B., Hirschman Elizabeth C., The Experiential Aspects of Consumption: Consumer Fantasies, Feelings and Fun, Journal of Consumer Research, vol. 9, n. 2, 1982, pp. 132-140.

Medway Dominic, Alexander Andrew, Bennison David, Warnabay Gary, Retailers' Financial Support for Town Centre Management, International Journal of Retail \& Distribution Management, vol. 27, n. 6, 1999. http://dx.doi.org/10.1108/09590559910278614

McKinsey Global Institute, Urban World: Mapping the Economic Power of Cities, 2011.

O'Shaughnessy John, O'Shaughnessy Nicholas, Jackson, Marketing the Consumer Society and Hedonism, European Journal of Marketing, vol. 36, n. 5/6, 2002, pp. 524-547. http://dx.doi.org/10.1108/03090560210422871

Padilla Charlette, Eastlick Mary, Ann, Exploring Urban Retailing and CBO Revitalisation Strategies, International Journal of Retail and Distribution Management, vol. 37, n. 1, 2008, pp. 7-23. http://dx.doi.org/10.1108/09590550910927135.

Peterson Robert, Balasubramanian Sridhar, Retailing In The 21st Century: Relfections and Prologue to Research, Journal of Retailing, vol. 78, n. 8, 2002, pp. 9-16. http://dx.doi.org/10.1016/S0022-4359(01)00062-8

Pine B.Joseph II, Gilmore James H., The Experience Economy. Work Is Theatre \& Every Business a Stage, Harward Business School Press, Boston, Massachussetts, 1999.

Rieunier Sophie, (ed.), Le Marketing Sensoriel du Point de Vente, Paris, Dunod, 2002. 
Spangerberg Eric R., Any E. Crowley, Pamela W. Henderson, Improving the Store Environment: do Olfactory Cues Affect Evalutations and Behaviors? Journal of Marketing, vol. 60, april, 1996, pp. 67-80. http://dx.doi.org/10.2307/1251931

Stoltman Jeffrey J., Gentry James W., Anglin Kenneth A., Burns Alvin C., Situational Influences on the Consumer Decision Sequence, Journal of Business Research, vol. 21, 1990, pp. 195-207. http://dx.doi.org/10.1016/0148-2963(90)90028-C

Schmitt Bernd H., Simonson Alex (1997), Marketing Aesthetics: The Strategic Management of Brands. Identity and Image. New York, The Free Press.

Schmitt Bernd H., Experiential Marketing, New York, Free Press, 1999.

Schmitt Bernd H., Rogers David L., Vrotsos Karen, There's no Business that's not Show Business Marketing in an Experience Culture, New Jersey, Prentice Hall, 2003.

Tomalin Christina, Town Centre Health Checs: Some Developments From Practice, Planning Practice \& Research, vol. 12, n. 4, 1997.

http://dx.doi.org/10.1080/02697459716392

Tomalin Christina, Pal John, Local Authority Responses to Retail Change: The Case for Town Centre Management, International Journal of Retail and Distribution Management, vol. 22, n. 6 , 2004. http://dx.doi.org/10.1108/09590559410070330

Turley L. W., Chebat Jean Charles, Linking Retail Strategy, Atmospheric Design and Shopping Behaviour, Journal of Marketing Management, vol. 18, 2002, pp. 125-144. http://dx.doi.org/10.1362/0267257022775891

Warnaby Gary, Bennison David, Davies Barry J., Hughes Howard, People and Partnership: Marketing Urban Retailing, International Journal of Retail \& Distribution Management, vol. 32 n. 11, 2004, pp. 545-556. http://dx.doi.org/10.1108/09590550410564773

Warnaby Gary, Bennison David, Davies Barry J., Marketing Communications in Planned Shopping Centres: Evidence from the UK, International Journal of Retail \& Distribution Management, vol. 33, n. 12, 2005, pp. 893-904. http://dx.doi.org/10.1108/09590550510634620

Whysall Paul, A Stakeholder Perspective On The City Centre, Marketing \& Managing Urban Centres, Proceedings, The Manchester Metropolitan University, 1998.

Wolf Michael J., The Entertainment Economy. How Mega-Media Forces Are Transforming Our Lives, New York, Times Books, Random House, 1999.

\section{Notes}

1 This is a new type of structure that meets requirements that do not exclusively mean the multiplication of the number of cinema screens, but also to a more complex conception of the modernisation of cinema facilities, where the performance, delivered with high technological standards, is combined with commercial consumption and other forms of entertainment.

${ }^{2}$ Write about Brondoni Silvio M.: 'In today's economies, companies do battle in global markets characterized by highly intense competition and an abundance of offerings. In over-supplied markets, basic product use characteristics are being constantly improved and offered at ever lower prices and in quantities over and above the capacity for market absorption. Physical product characteristics tend to become standardized under such conditions and consequently lose the part they play in competitive product differentation...' Cf. Brondoni Silvio M. (2000-2001), Brand Policy and Brand Equity, Symphonya Emerging Issues in Management (symphonya.unimib.it), 1, p. 5.

${ }^{3}$ Of the 8 integrated retail structures, 6 fall into the category of traditional purpose-built shopping centres, while 2 are considered as innovative retail projects. The cases examined have a GLA (Gross 
Leasable Area) of between 11,500 and 50,000 sq m, and represent a privileged observatory to investigate the propensity to become centres able to respond positively to the current trend towards intangible consumption, by studying the composition of entertainment services and the main integration dynamics between shopping and entertainment that exist there.

${ }^{4}$ This justifies the lack of ancient monuments of architectural treasures from the past in the city centre. One of the most significant historical attractions is the house in Corso Manthoné where the poet Gabriele d'Annunzio was born.

${ }^{5}$ For example, in the clothing sector, the boutiques in the city centre offer items from the latest collections of the most prestigious designers, unlike the nearby Factory Outlet Village which offers items that were part of the previous year's collections. 